\title{
Knowledge Intensive Herbal City Community Innovative Services in Thailand: Role of Solutions Provision Competence
}

\author{
Yananda Siraphatthada ${ }^{1} \&$ Duangkamol Thitivesa ${ }^{1}$ \\ ${ }^{1}$ Suan Sunandha Rajabhat University, Bangkok, Thailand \\ Correspondence: Duangkamol Thitivesa, Suan Sunandha Rajabhat University, Bangkok, Thailand. E-mail: \\ duangkamol.th@ssru.ac.th
}

Received: July 17, 2020

doi:10.5430/rwe.v11n6p324
Accepted: September 4, 2020

Online Published: December 20, 2020

URL: https://doi.org/10.5430/rwe.v11n6p324

\begin{abstract}
Various studies examined the knowledge management among different organizations; however, these practices were not examined in the herbal community of Thailand. The role of information extraction and information utilization is not discussed in literature along with the herbal companies of Thailand. Therefore, by considering knowledge management, this study examined the role of information extraction and information utilization in firm competency. The objective of this study is to examine the role of knowledge intensive innovative services of herbal city community in firm competency. The relationship between information extraction, information utilization, innovative services and firm competency was examined to achieve this objective. By carrying out a questionnaire survey, 500 questionnaires were distributed among the herbal city community in Thailand. Results of the study show that; information extraction has positive role to improve firm competency and innovative services. Information utilization has positive role to enhance firm competency and innovative services. Finally, innovative services show positive effect on firm competency.
\end{abstract}

Keywords: knowledge management, herbal city community, information extraction, information utilization, innovative services and firm competency

\section{Introduction}

Herbal community is playing an important role in the society. Apart from other medicine companies, herbal companies have its own importance for the society. Now a day, herbal community is competing with the pharmaceutical companies. The medicine prepared with the help of natural things like plants is important against various diseases with no side effect. Herbal medicine is one of the studies of botany as well as the utilization of medicinal plants to prepare various medicines. Plants have been the foundation for medical treatments with the help of much of human history, as well as such traditional medicine is still extensively practiced today. Therefore, herbal medicine companies have importance in the society (Dachyar \& Tjiptadi, 2019; Shen et al., 2020).

Importance of herbal medicine is increasing along with other medicine companies. Especially, in Thailand, these companies have important role in the community. In Thailand, herbal city community is also increasing which required better strategies to enhance the market share. Government is also making positive efforts to support herbal companies based on increasing importance of these companies. Figure 1 shows the global market of herbal medicines. In western culture, this market has significant share. Along with west, Chinese traditional medicines are also very effective and capturing the market share. Therefore, herbal medicines are also capturing the significant market share (Jeung, Choi, Jo, \& Song, 2018). 


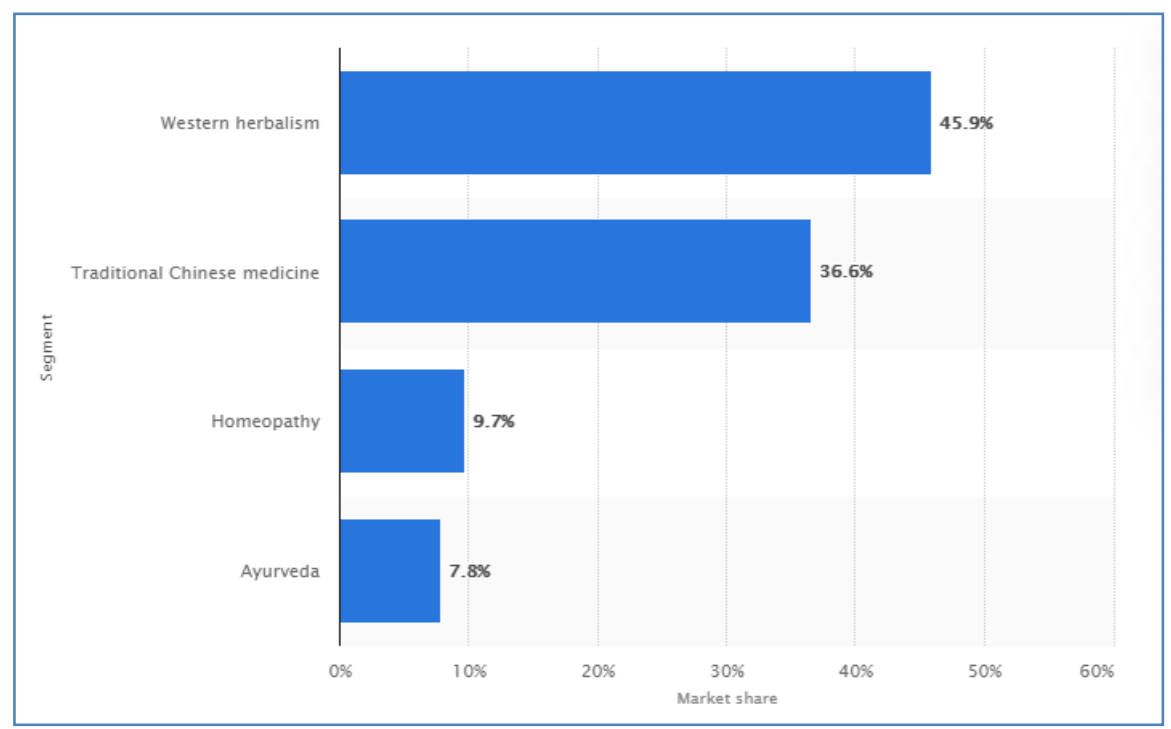

Figure 1. Herbal medicine market globally

Source: Statista

However, these companies are lacking innovative services along with the other medicine companies such as pharmaceutical companies. That is the reason market share is low as compared to other companies. Low innovative services by the companies shows negative effect on firm competency. This study proposed that; herbal medicine companies can enhance innovative services and firm competency with the help of knowledge management. As previous studies show that knowledge management has important role in innovation (Shujahat et al., 2019; Zizakov, Vulanovic, Delic, Vrhovac, \& Vasic, 2019). In this study knowledge management is treated through two elements; information extraction and information utilization. Therefore, the objective of this study is to examine the role of knowledge intensive innovative services of herbal city community in firm competency.

\section{Literature Review}

Knowledge is one of the most powerful to improve the organization performance. The assets of the companies have vital importance. It is intangible asset which has really important for the company policies as well as strategies. Most of the company decisions are based on the valuable information from the market as well as from the company employees. Decisions cannot be taken until unless companies do not have proper information's. Therefore, organizations always focus to collect better information from the market and to utilize for the decision-making purposes. Previous studies also provided the importance of knowledge management among various organizations (Sokhanvar, Matthews, \& Yarlagadda, 2014). However, it is important to highlight knowledge management activities among medicine companies. Medicine companies are most crucial in the society and required better knowledge as well as capabilities to enhance new idea generation to develop new products. New idea generation through proper knowledge management is most important to develop new medicines. As the diseases are increasing day by day which requires new and latest medicines to recover form disease. In this direction, knowledge is most important for the medicine companies which require the management of information both from external as well as internal sources. According to the current study, there are two major elements which lead to the proper knowledge management. The first element is information extraction and the second element is information utilization. Both these elements have major role in knowledge management which shows the influence on innovative services by the herbal community and finally increases the firm competency. Therefore, the relationship between information extraction, information utilization, innovative services and firm competency is given in Figure 1. This relationship shows that the relationship between information extraction, information utilization and innovative services has vital role to enhance firm competency. Particularly, in the herbal community, the medicine preparation for the specific disease always requires specific information which may lead to the quality medicine. However, ineffective information may lead to the low-quality medicine preparation. Therefore, for the knowledge management among herbal medicine companies, it is very important to introduce information extraction and information utilization to develop a good product. Number of studies has found that information management is key for better knowledge 
utilization (Kyunghyun et al., 2016). First of all, it is important to extract the information form various areas including both internal and external areas. After that it is required to implement this information for better knowledge management and to generate better ideas.

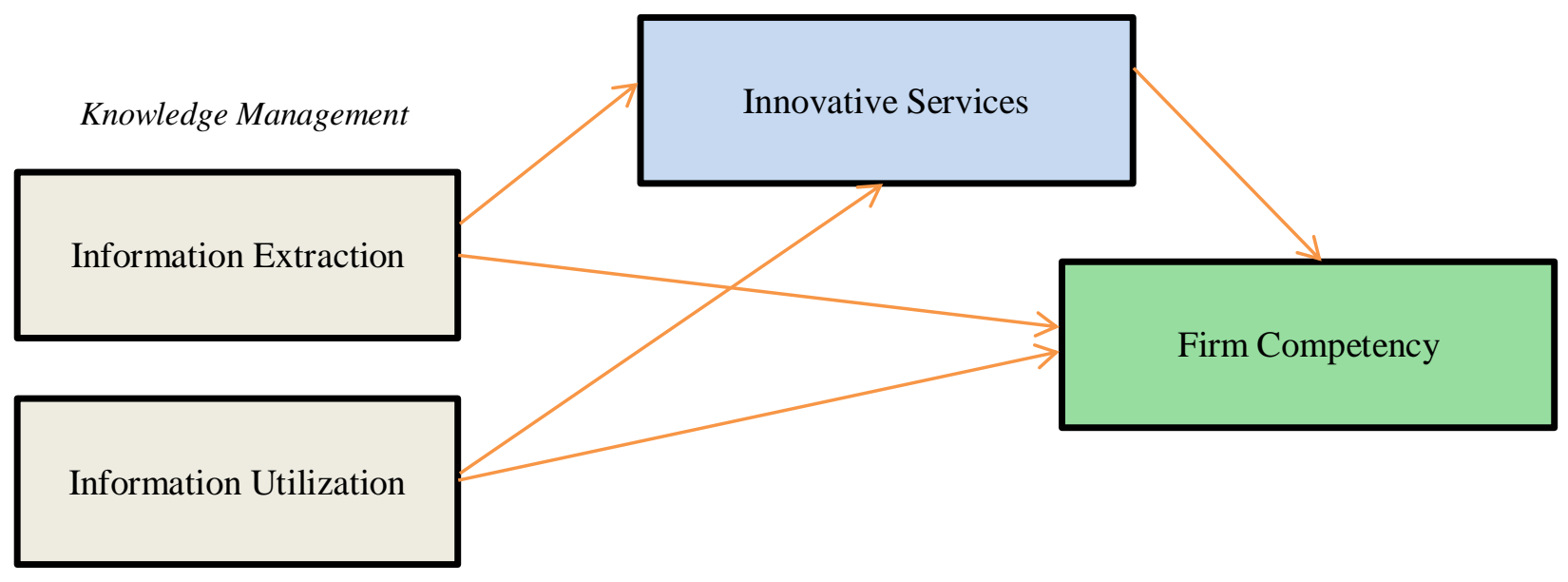

Figure 2. Theoritical framework of the study showing the relationship between information extraction, information utilization, innovative services and firm competency

\subsection{Information Extraction and Firm Competency}

Information extraction is one of the important tasks of automatically extracting structured information from unstructured and/or semi-structured machine-readable documents as well as other electronically denoted sources. This information is quite crucial to enhance idea generation. In the context of the current study, information extraction is based on the collection of information from outside the boundaries of the firm. Information collection from various stakeholders is important to develop new products which are vital for the business. Information from the market could be the basis of new product development. Only the information extraction is not important, the valuable information extraction is most important for the companies. Because companies collect knowledge in huge amount from the market, however, the extraction of valuable information for idea generation is most important. Unsuitable or irrelevant information collection may lead to the negative effect on the operations of the study. Irrelevant knowledge from the market is the wastage of time. Therefore, proper knowledge extraction is most important in herbal community. Finally, information extraction from the market has positive role on firm competency. Increase in the information extraction increases the firm competency. Because competencies are always required better information extraction. Therefore, the relationship between information extraction and firm competency lead to the better opportunity for companies. It is also given in the previous studies (Fauzan, Prajanti, \& Wahyudin, 2019; Saleh, Zolait, Ali, \& Wali, 2019; Ume \& Ndubuaku, 2019; Usman \& Siddiqui, 2019).

Hypothesis 1. Information extraction has positive effect on firm competency.

\subsection{Information Utilization and Firm Competency}

Information utilization is the processing of data as well as information within the network, systems as well as applications. It is most important area of knowledge management. Because after the extraction of knowledge or information from the whole given information, the next step is to utilize the information for main objective. Utilization of new information to develop new product is most important. The extraction of information is useless if it is not utilized. In fact, the proper utilization is most important. Sometimes, employee of the organization extracts the valuable knowledge form information (Ali, Naveed, ul Hameed, \& Rizvi, 2018; Hamid, Shahid, Hameed, Amin, \& Mehmood, 2019; Wang \& Lei, 2020; Woon, Singh, \& Singh, 2019; Yousuf, Ahmed, Akther, \& Sumon, 2019), but they cannot utilize this knowledge which cannot produce valuable outcomes for the company. Therefore, after the proper extraction of information, utilization through a proper way, or through a proper channel is very important for the companies to generate new ideas. As the herbal companies are linked with the new medicine development, therefore, for these companies, to develop new medicine, information utilization is key. As shown in previous studies 
that information utilization is very important (Williams, Awoyemi, Parakoyi, Jolayemi, \& Akande, 2019; Yamada et al., 2019). Therefore, the utilization of information is positively associated with the companies of the firms. Because information utilization has also based on the competency of the firm. Better competency of the firm has better capability to utilize the information. However, low level capability of the firm may not properly utilize the information. Better information utilization also increases the firm competency. It is one of the additions to the competency of the firm. Hence, from the above discussion, following hypothesis is proposed;

Hypothesis 2. Information utilization has positive effect on firm competency.

\subsection{Information Extraction and Innovative Services}

Innovation is the application of new idea as well as new application to the system (Hameed, Basheer, Iqbal, Anwar, $\&$ Ahmad, 2018). It is the addition to the existing process to increase the efficiency. It can be described as it is the improvement in the working of organizations which improves the operation. In this era, the improvement in the technology process or any operations is most important to increase the performance. On the other hand, innovative services mean innovation in the various services provided by the companies. Innovative services denote to the addition of something new in the existing services or the provision of totally new services. This study shows that information extraction lead to the innovative services. As information is required to bring innovation, that is the reason information extraction lead to the innovative services among the medicine companies. The relationship between innovation in services and information is available and discussed in the literature (Nestle, Täube, Heidenreich, \& Bogers, 2018).

Hypothesis 3. Information extraction has positive effect on innovative services.

\subsection{Information Utilization and Innovative Services}

After the information extraction form the bundle of information received from outside the organizations, next step is information utilization for the major purpose which has significant role in innovative services. Innovation is always key to the success for the companies. In this environment of high competition among the medicine companies, it is very important to have innovative services. Survival in the market is also based on the innovative services. Due to increase in the number of medicine companies, the innovative services are also increasing. That is the reason companies always require better innovative services for the customers. The survival of medicine companies is to provide the innovative services in competition. Especially, it is more important for the herbal medicine companies because these companies have stiff competition with other medicine companies. That is the reason, previous studies showing high importance of innovative services in various organizations (Costello, 2018; Paglierani et al., 2020).

Hypothesis 4. Information utilization has positive effect on innovative services.

\subsection{Innovative Services and Firm Competency}

In the above discussion, it is given that knowledge management has important role for innovative services. Information extraction and information utilizations has positive role to enhance innovative services among the herbal companies of Thailand. Both information extraction and information utilizations have significant effect on innovative services development in the herbal community of Thailand. This improvement in innovative services due to information extraction and information utilizations has positive role in firm competency. Firm competency is the most important element which requires for the companies to enhance the performance. Firm competency can be described as, "a harmonized combination of numerous resources as well as skills that differentiate a firm in the marketplace" and consequently are the basis of firms' competitiveness. These competencies of the firm are influenced by the innovative services. Innovative services provide the competitive edge to the companies to enhance the overall performance. In this direction, it is given in previous studies that company's core competencies are vital for the performance (Freixanet \& Churakova, 2018; Mohammed, Hu, Obrenovic, \& Aina, 2017).

Hypothesis 5. Innovative services have positive effect on firm competency.

\subsection{Mediation Effect}

Above section shows that knowledge management is influential in respect to the firm competency. It is also influential in respect to the innovation services. As both information extraction and information utilization has positive role in innovative services and firm competency. The above discussion shows that knowledge management has significant role in firm competency and innovative services. Significant role of information extraction ad information utilization is found in relation to the firm competency and innovative services. Moreover, innovative services have positive influence on firm competency. Thus, all the relationship are significant, therefore, according to the Baron and Kenny (1986), innovative services can be used as mediating variables. This study considered 
innovative services as mediating variables between information extraction and firm competency. It is also used as mediating variable between information utilization and firm competency. The mediation effects are proposed in following hypotheses;

Hypothesis 6. Innovative services mediate the relationship between information extraction and firm competency.

Hypothesis 7. Innovative services mediate the relationship between information utilization and firm competency.

\section{Research Methodology}

The relationship between information extraction, information utilization and innovative services was examined by using primary data. Data were collected from herbal city community of Thailand. For this purpose of data collection, a questionnaire was designed, and various measures was developed related to the relationship between information extraction, information utilization and innovative services. Different scale items were formulated and used in questionnaires for data collection. Therefore, survey questionnaire, a most appropriate tool was used for data collection (Bowling, Bond, Jenkinson, \& Lamping, 1999; Cossiga, 2018; Zafarullah, 2018).

Finally, a questionnaire was sent to the herbal community Thailand for data collection. Questionnaires were distributed through simple random sampling which is most suitable in the current situation to collect data from herbal community (Siuly, Li, \& Wen, 2011). Hence, quantitative research was used as it is suitable for hypotheses testing with the help of primary data. One point of time was chosen to collect the data from respondents which make this study as a cross-sectional research design. Thus, by carrying out a questionnaire survey, 500 questionnaires were distributed among the herbal city community in Thailand. 270 questionnaires were used to test the relationship between variables.

\section{Data Analysis and Findings}

Data analysis is started with the examination of missing value (Aydin \& ŞENOĞLU, 2018). Table 1 shows that all the missing values are removed, and data has no missing value. Outlier in the data was also removed and there is no outlier in the data. Further data statistic including mean, median and normality is also given for more clarity.

Table 1. Data statistics

\begin{tabular}{lccccccccc}
\hline & No. & Missing & Mean & Median & Min & Max & SD & Kurtosis & Skewness \\
\hline IE1 & 1 & 0 & 3.575 & 4 & 1 & 5 & 1.054 & -0.501 & -0.55 \\
IE2 & 2 & 0 & 3.099 & 4 & 1 & 5 & 1.166 & -1.653 & -1.448 \\
IE3 & 3 & 0 & 3.694 & 4 & 1 & 5 & 1.32 & -0.527 & -0.826 \\
IE4 & 4 & 0 & 3.646 & 4 & 1 & 5 & 1.374 & -0.724 & -0.751 \\
IE5 & 5 & 0 & 2.991 & 4 & 1 & 5 & 1.38 & -0.673 & -0.801 \\
IE6 & 6 & 0 & 3.467 & 4 & 1 & 5 & 1.059 & -1.661 & -0.409 \\
IE7 & 7 & 0 & 3.493 & 4 & 1 & 5 & 1.237 & -0.857 & -1.444 \\
IU1 & 8 & 0 & 3.663 & 4 & 1 & 5 & 1.298 & -0.479 & -0.822 \\
IU2 & 9 & 0 & 3.66 & 4 & 1 & 5 & 1.346 & -0.62 & -0.799 \\
IU3 & 10 & 0 & 9.994 & 4 & 1 & 5 & 1.039 & -0.471 & -0.531 \\
IU4 & 11 & 0 & 3.535 & 4 & 1 & 5 & 1.171 & -1.654 & -1.479 \\
IU5 & 12 & 0 & 3.592 & 4 & 1 & 5 & 1.389 & -0.715 & -0.777 \\
IS1 & 13 & 0 & 3.075 & 4 & 1 & 5 & 1.052 & -0.486 & -0.559 \\
IS2 & 14 & 0 & 3.507 & 4 & 1 & 5 & 1.166 & -0.601 & -0.501 \\
IS3 & 15 & 0 & 3.453 & 4 & 1 & 5 & 1.197 & -0.523 & -1.591 \\
IS4 & 16 & 0 & 3.453 & 4 & 1 & 5 & 1.225 & -1.637 & -0.546 \\
IS5 & 17 & 0 & 3.06 & 4 & 1 & 5 & 1.22 & -0.807 & -0.424 \\
IS6 & 18 & 0 & 3.467 & 4 & 1 & 5 & 1.048 & -0.723 & -0.509 \\
FC1 & 19 & 0 & 3.527 & 4 & 1 & 5 & 1.178 & -1.517 & -1.54 \\
FC2 & 20 & 0 & 3.569 & 4 & 1 & 5 & 1.086 & -0.422 & -0.532
\end{tabular}




\begin{tabular}{llllllllll} 
FC3 & 21 & 0 & 3.086 & 4 & 1 & 5 & 1.286 & -0.601 & -0.712 \\
FC4 & 22 & 0 & 3.652 & 4 & 1 & 5 & 1.071 & -0.397 & -0.666 \\
FC5 & 23 & 0 & 3.618 & 4 & 1 & 6 & 1.259 & -0.762 & -1.498 \\
FC6 & 24 & 0 & 3.007 & 4 & 1 & 6 & 1.119 & -1.519 & -0.438 \\
FC7 & 25 & 0 & 3.547 & 4 & 1 & 5 & 1.097 & -0.723 & -0.484 \\
\hline
\end{tabular}

Note; IE = Information Extraction; IU = Information Utilization; IS = Innovative Services; FC = Firm Competency

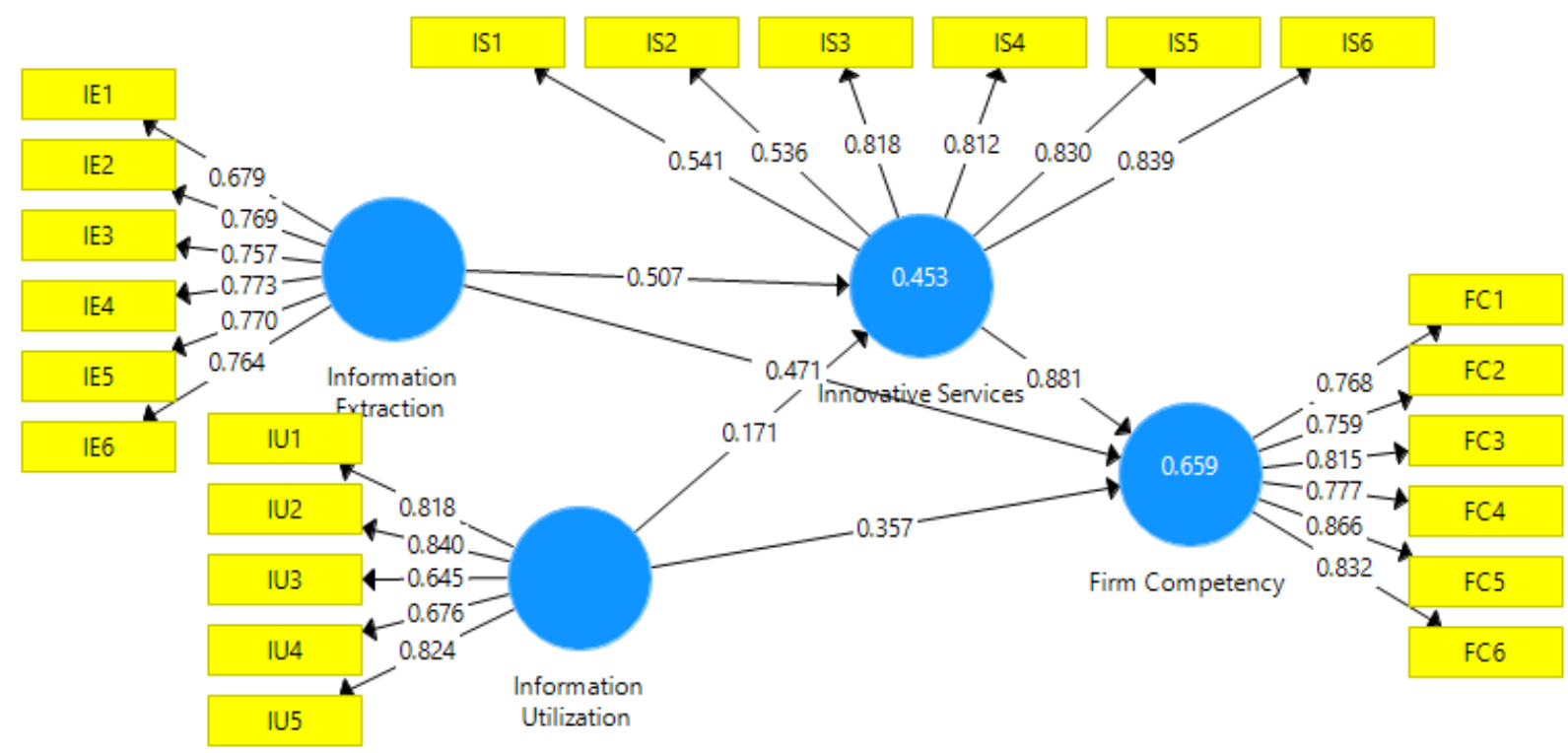

Figure 3. Measurement model

It is given in Figure 3 that; information extraction is measured by using six scale items. All items have factor loadings above 0.7 , however, one item have factor loadings is 0.679 . Information utilization is measured through five scale items, two items have factor loadings below 0.7 and above 0.6 , all other items are above 0.7. Innovative services are measured by using six scale items. Three scale items have factor loadings above 0.7 and two items have factor loadings below 0.6 and above 0.5 which is acceptable. Finally, firm competency was measured through six scale items and all have factor loadings above 0.7. The factor loadings were examined through confirmatory factor analysis (CFA) which is most recommended (Henseler \& Chin, 2010; Henseler, Ringle, \& Sinkovics, 2009; Ul-Hameed, Mohammad, \& Shahar, 2018). Factor lodgings are also given in Table 2.

Table 2. Factor loadings

\begin{tabular}{lcccc}
\hline & $\begin{array}{c}\text { Firm } \\
\text { Competency }\end{array}$ & $\begin{array}{c}\text { Information } \\
\text { Extraction }\end{array}$ & $\begin{array}{c}\text { Information } \\
\text { Utilization }\end{array}$ & $\begin{array}{c}\text { Innovative } \\
\text { Services }\end{array}$ \\
\hline FC1 & 0.768 & & & \\
FC2 & 0.759 & & & \\
FC3 & 0.815 & & & \\
FC4 & 0.777 & & & \\
FC5 & 0.866 & & \\
FC6 & 0.832 & & \\
IE1 & & 0.679 & \\
IE2 & & 0.769 &
\end{tabular}




\begin{tabular}{|c|c|c|c|}
\hline IE3 & 0.757 & & \\
\hline IE4 & 0.773 & & \\
\hline IE5 & 0.77 & & \\
\hline IE6 & 0.764 & & \\
\hline IS1 & & 0.541 & \\
\hline IS2 & & 0.536 & \\
\hline IS3 & & 0.818 & \\
\hline IS4 & & 0.812 & \\
\hline IS5 & & 0.83 & \\
\hline IS6 & & 0.839 & \\
\hline IU1 & & & 0.818 \\
\hline IU2 & & & 0.84 \\
\hline IU3 & & & 0.645 \\
\hline IU4 & & & 0.676 \\
\hline IU5 & & & 0.824 \\
\hline
\end{tabular}

Note; IE = Information Extraction; IU = Information Utilization; IS = Innovative Services; FC = Firm Competency

Results in Table 3 show the results of reliability and validity. According to Hair, Hollingsworth, Randolph, and Chong (2017), composite reliability and average variance extracted (AVE) should be above 0.7 and 0.5 respectively. It is given in Table 3 that; information extraction, information utilization, innovative services and firm competency have $\mathrm{CR}$ above 0.7. It is also found that; information extraction, information utilization, innovative services and firm competency have AVE above 0.5 which confirmed the convergent validity.

Table 3. Reliability and convergent validity

\begin{tabular}{lcccc}
\hline & Cronbach's Alpha & rho_A & $\begin{array}{l}\text { Composite } \\
\text { Reliability }\end{array}$ & (AVE) \\
\hline Firm Competency & 0.89 & 0.892 & 0.916 & 0.646 \\
Information Extraction & 0.847 & 0.847 & 0.887 & 0.567 \\
Information Utilization & 0.818 & 0.821 & 0.875 & 0.585 \\
Innovative Services & 0.826 & 0.84 & 0.877 & 0.551 \\
\hline Note; IE = Information Extraction; IU = Information Utilization; IS = Innovative Services; FC = Firm Competency
\end{tabular}

Note; IE = Information Extraction; IU = Information Utilization; IS = Innovative Services; FC = Firm Competency

To measure the discriminant validity, there are various methods. Fornell and Larcker (1981) provided AVE square root. The HTMT ratio is also widely used method for discriminant validity. However, this study used cross-loadings to examine the discriminant validity which is also an appropriate method. It is given in Table 4.

Table 4. Cross-loadings

\begin{tabular}{lcccc}
\hline & $\begin{array}{c}\text { Firm } \\
\text { Competency }\end{array}$ & $\begin{array}{c}\text { Information } \\
\text { Extraction }\end{array}$ & $\begin{array}{c}\text { Information } \\
\text { Utilization }\end{array}$ & $\begin{array}{c}\text { Innovative } \\
\text { Services }\end{array}$ \\
\hline FC1 & 0.768 & 0.426 & 0.442 & 0.71 \\
FC2 & 0.759 & 0.324 & 0.34 & 0.571 \\
FC3 & 0.815 & 0.399 & 0.417 & 0.651 \\
FC4 & 0.777 & 0.375 & 0.381 & 0.622 \\
FC5 & 0.866 & 0.353 & 0.37 & 0.655 \\
FC6 & 0.832 & 0.352 & 0.373 & 0.631
\end{tabular}




\begin{tabular}{l|c|c|c|c} 
IE1 & 0.305 & 0.679 & 0.615 & 0.547 \\
IE2 & 0.261 & 0.769 & 0.649 & 0.519 \\
IE3 & 0.417 & 0.757 & 0.707 & 0.49 \\
IE4 & 0.425 & 0.773 & 0.61 & 0.474 \\
IE5 & 0.409 & 0.77 & 0.708 & 0.475 \\
IE6 & 0.263 & 0.764 & 0.65 & 0.527 \\
IS1 & 0.287 & 0.555 & 0.603 & 0.541 \\
IS2 & 0.282 & 0.549 & 0.658 & 0.536 \\
IS3 & 0.724 & 0.403 & 0.884 & 0.818 \\
IS4 & 0.741 & 0.418 & 0.839 & 0.812 \\
IS5 & 0.705 & 0.427 & 0.839 & 0.83 \\
IS6 & 0.704 & 0.417 & 0.887 & 0.839 \\
IU1 & 0.421 & 0.739 & 0.818 & 0.885 \\
IU2 & 0.434 & 0.759 & 0.84 & 0.881 \\
IU3 & 0.285 & 0.667 & 0.645 & 0.841 \\
IU4 & 0.282 & 0.75 & 0.676 & 0.831 \\
IU5 & 0.415 & 0.754 & 0.824 & 0.879 \\
\hline
\end{tabular}

Note; IE = Information Extraction; IU = Information Utilization; IS = Innovative Services; FC = Firm Competency

Figure 4 shows the direct effect of information extraction on firm competency. PLS structural model is used for hypotheses testing (Hair Jr, Sarstedt, Hopkins, \& Kuppelwieser, 2014; Hair, Ringle, \& Sarstedt, 2013; Hair, Sarstedt, Pieper, \& Ringle, 2012). It also shows the direct effect of information extraction on innovative services. Furthermore, the direct effect of information utilization was examined on firm competency. Similarly, the direct effect of information utilization was examined on innovative services. To test the hypotheses, 1.96 minimum level of $t$-values was considered. It is found that information extraction has positive effect on firm competency. Information extraction also has positive effect on innovative services. Along with this, information utilization has positive effect on firm competency and also shows positive effect on innovative services. Furthermore, information utilization has positive effect on innovative service and firm competency. Finally, it is found that innovative services cause to increase firm competency.

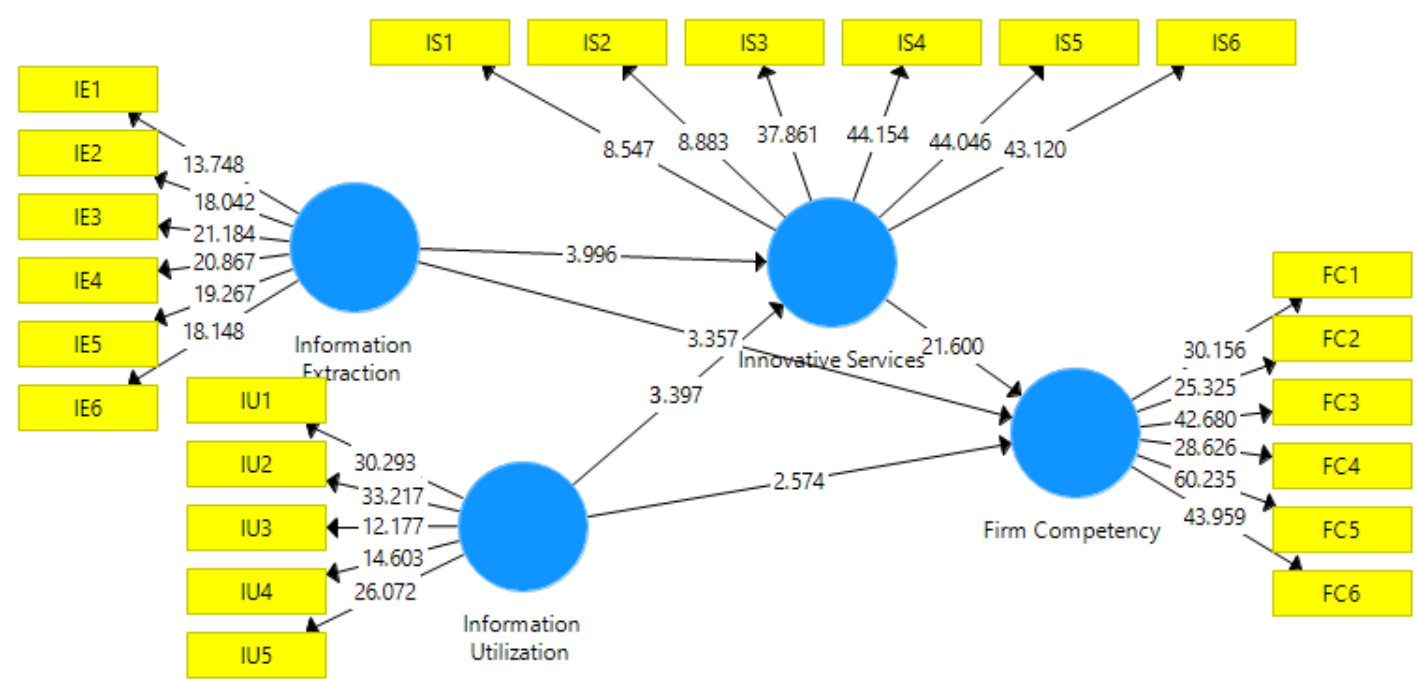

Figure 4. Structural model 
Table 5. Direct effect results

\begin{tabular}{lccccc}
\hline & $(\mathbf{O})$ & (M) & SD & T Statistics & P Values \\
\hline Information Extraction -> Firm Competency & 0.471 & 0.466 & 0.14 & 3.357 & 0.001 \\
Information Extraction -> Innovative Services & 0.507 & 0.504 & 0.127 & 3.996 & 0 \\
Information Utilization -> Firm Competency & 0.357 & 0.351 & 0.139 & 2.574 & 0.01 \\
Information Utilization -> Innovative Services & 0.171 & 0.172 & 0.051 & 3.397 & 0.002 \\
Innovative Services -> Firm Competency & 0.881 & 0.885 & 0.041 & 21.6 & 0
\end{tabular}

Note; IE = Information Extraction; IU = Information Utilization; IS = Innovative Services; FC = Firm Competency

Results of the mediation effect are given in Table 6. The mediation effect of innovative services was examined between information extraction and firm competency. The other mediation effect was examined between information utilization and firm competency. The mediation effect of innovative services was examined between information extraction and firm competency which found t-value 3.764 and the mediation effect between information utilization and firm competency found t-value 1.396. Hence, the mediation effect of innovative services was examined between information extraction and firm competency, which is significant, however, the other mediation effect is insignificant. Innovative services reflect the positive effect of information extraction on firm competency. Figure 5 also shows the mediation effect.

Table 6. Indirect effect results

(O) $\quad$ (M) $\quad$ SD $\quad$ T Statistics $\quad$ P Values

Information Extraction -> Innovative Services -> Firm

Competency

0.446

0.447

0.12

3.734

0

Information Utilization -> Innovative Services -> Firm

Competency

0.151

0.151

0.108

1.396

0.163

Note; IE = Information Extraction; IU = Information Utilization; IS = Innovative Services; FC = Firm Competency

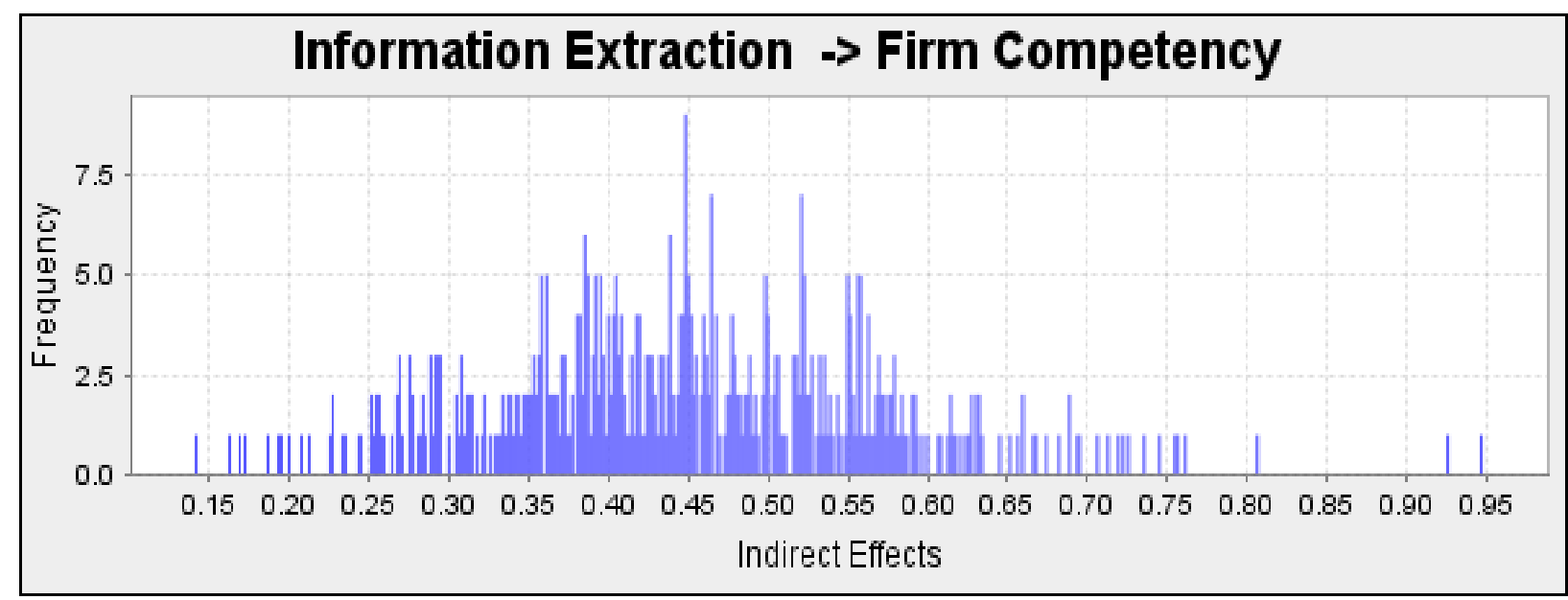

Figure 5. Indirect effect: Information extraction -> Innovative services -> Firm competency 
R-square value is given in Figure 3 which is 0.659 for firm competency. It shows that all the constructs; information extraction, information utilization and innovative services are expected to bring $65.9 \%$ change in firm competency which is moderate (Chin, 1998). R-square for innovative services is 0.453 which is moderate and shows that; information extraction and information utilization are expected to bring $45.3 \%$ change in innovative services.

\section{Conclusion}

The objective of this study was to examine the role of knowledge intensive innovative services of herbal city community in firm competency. The relationship between information extraction, information utilization, innovative services and firm competency was examined. Questionnaires were distributed among the herbal city community in Thailand. Data were analyzed by using Partial Least Square (PLS).

It is found that knowledge management has most important role in competency development. It is revealed that knowledge management among herbal city community has positive effect on firm competency. Better knowledge management practices have the power to increase firm competency. Increase in knowledge management practices increase the firm competency of herbal community. Therefore, better knowledge management practices should be applied among the companies to promote competency.

Results of the study show that; information extraction has positive role to improve firm competency and innovative services. It indicates that increase in information extraction increases the firm competency. Along with this, it also increases the firm innovative services which are most important in the survival of herbal companies. Therefore, innovative services and firm competency can be increased with the help of information extraction. Furthermore, information utilization has positive role to enhance firm competency and innovative services. Increase in the information utilization increases the innovative services in herbal companies. Knowledge management through information utilization has positive influence on innovative service. Hence, both information extraction and information utilization have positive role to enhance the herbal city community innovative services and firm competency. Finally, innovative services show positive effect on firm competency. Increase in innovative services increases the firm competency. Furthermore, it is found that innovative services have significant mediation effect. The mediation effect of innovative services was examined between information extraction and firm competency. The other mediation effect was examined between information utilization and firm competency. The mediation effect between information extraction and firm competency found significant. Therefore, innovative services reflect the positive effect of information extraction on firm competency among herbal medicine companies of Thailand.

\subsection{Implications of the Study}

The current study is valuable to contribute to the literature. As the role of knowledge management in firm competences is not examined in other studies. This study is unique because this study tested the role of information extraction on firm competency and innovative services. The study also contributed by testing the effect of information utilization in firm competency and innovative services. Therefore, this study is unique as this study examined the relationship between information extraction, information utilization, innovative services and firm competency which is not examined in previous studies. Along with this, it important because there are very rare studies carried out on herbal community of Thailand in respect to the social sciences by involving knowledge-based relationship with these medicine companies. Apart from that; this study has vital practical implications. Practically, results of this study are important for the management of herbal companies. As these studies suggested that herbal companies should enhance the firm competency with the help of proper information extraction and information utilization in new product development or any idea generation. This study also suggested that management should improve innovative services to enhance firm competency.

\section{Limitations and Future Directions}

Herbal community of Thailand is discussed in the current study. Thailand is a developing country where the herbal medicine is increasing. The situation may be different where herbal medicines have low focus, therefore, the results can be different. Future studies should be carried out among various other countries. Moreover, this study is considered the two elements of knowledge management, including; information extraction and information utilization. The other important elements of knowledge management should also be discussed. The element of knowledge acquisition is an important element which is missing in this study. Therefore, future study should include knowledge acquisition while examining the role of knowledge management among herbal companies of Thailand. 


\section{References}

Ali, G., Naveed, F., ul Hameed, W., \& Rizvi, T. (2018). The Effect of Task Illegitimacy on the Wellness of Employees. UCP Management Review (UCPMR), 2(2), 5-20.

Aydin, D., \& ŞENOĞLU, B. (2018). Estimating the Missing Value in One-Way Anova Under Long-Tailed Symmetric Error Distributions. Sigma: Journal of Engineering \& Natural Sciences/Mühendislik ve Fen Bilimleri Dergisi, 36(2).

Baron, R. M., \& Kenny, D. A. (1986). The moderator-mediator variable distinction in social psychological research: Conceptual, strategic, and statistical considerations. Journal of personality and social psychology, 51(6), 1173-1182.

Bowling, A., Bond, M., Jenkinson, C., \& Lamping, D. (1999). Short Form 36 (SF-36) Health Survey questionnaire: which normative data should be used? Comparisons between the norms provided by the Omnibus Survey in Britain, the Health Survey for England and the Oxford Healthy Life Survey. Journal of Public Health, 21(3), 255-270.

Chin, W. W. (1998). The partial least squares approach to structural equation modeling. Modern Methods for Business Research, 295(2), 295-336.

Cossiga, G. A. (2018). Signals from the world of economics. The price constant and the democratic issue. International Journal of Social and Administrative Sciences, 3(1), 1-21.

Costello, L. (2018). Mobile Technology and Academic Libraries: Innovative Services for Research and Learning. Robin Canuel and Chad Crichton, (eds.), for the Association of College and Research Libraries. Chicago: American Library Association, 2017, p. 284. College \& Research Libraries, 79(2), 291.

Dachyar, M., \& Tjiptadi, A. (2019). Original Equipment Manufacturer (OEM) Site Selection of Traditional Medicine Companies in Indonesia using Analytic Hierarchy Process (AHP) Method. Paper presented at the IOP Conference Series: Materials Science and Engineering.

F. Hair Jr, J., Sarstedt, M., Hopkins, L., \& G. Kuppelwieser, V. (2014). Partial least squares structural equation modeling (PLS-SEM) An emerging tool in business research. European Business Review, 26(2), 106-121.

Fauzan, S., Prajanti, S. D. W., \& Wahyudin, A. (2019). The Effect of Budgeting Quality and Human Resource Competency of School Financial Performance with Information Technology as a Moderating Variables. Journal of Economic Education, 8(2), 159-166.

Fornell, C., \& Larcker, D. F. (1981). Evaluating structural equation models with unobservable variables and measurement error. Journal of Marketing Research, 39-50.

Freixanet, J., \& Churakova, I. (2018). The impact of export promotion programs on firms' export competencies and performance in a transition economy: the case of Russian manufacturers. Journal of East-West Business, 24(4), 287-318.

Hair, J., Hollingsworth, C. L., Randolph, A. B., \& Chong, A. Y. L. (2017). An updated and expanded assessment of PLS-SEM in information systems research. Industrial Management \& Data Systems, 117(3), 442-458.

Hair, J. F., Ringle, C. M., \& Sarstedt, M. (2013). Partial least squares structural equation modeling: Rigorous applications, better results and higher acceptance.

Hair, J. F., Sarstedt, M., Pieper, T. M., \& Ringle, C. M. (2012). The use of partial least squares structural equation modeling in strategic management research: a review of past practices and recommendations for future applications. Long range planning, 45(5-6), 320-340.

Hameed, W. U., Basheer, M. F., Iqbal, J., Anwar, A., \& Ahmad, H. K. (2018). Determinants of Firm's open innovation performance and the role of R \& D department: an empirical evidence from Malaysian SME's. Journal of Global Entrepreneurship Research, 8(1), 29.

Hamid, S. N. A., Shahid, M. N., Hameed, W. U., Amin, M., \& Mehmood, S. (2019). Antecedents Of Job Stress And Its Impact On Nurse's Job Satisfaction And Turnover Intention In Public And Private Hospitals Of Punjab Pakistan. International Journal of Scientific \& Technology Research, 8(10), 129-137.

Henseler, J., \& Chin, W. W. (2010). A comparison of approaches for the analysis of interaction effects between latent 
variables using partial least squares path modeling. Structural Equation Modeling, 17(1), 82-109.

Henseler, J., Ringle, C. M., \& Sinkovics, R. R. (2009). The use of partial least squares path modeling in international marketing. New challenges to international marketing (pp. 277-319). Emerald Group Publishing Limited.

Jeung, C.-W., Choi, C.-H., Jo, H.-G., \& Song, M.-Y. (2018). Analysis of the Medical Market Share of Traditional East Asian Medicine (TEAM) in Taiwan Using National Health Insurance Research Database (NHIRD). Journal of Korean Medicine Rehabilitation, 28(1), 133-144.

Kyunghyun, K., Kang, K. D., HeeJin, R., Seok-Young, Y., Kim, S. U., Bitna, B., . . Chisung, K. (2016). Accident information management apparatus, vehicle including accident information management apparatus, and accident information management method: Google Patents.

Mohammed, A.-N. N. A. M., Hu, W., Obrenovic, B., \& Aina, A. A. M. (2017). An empirical assessment of the link between Decision support system (DSS) capabilities, competencies and firm performance: A mediating role of absorptive capacity. Paper presented at the Proceedings of the 2017 International Conference on Management Engineering, Software Engineering and Service Sciences.

Nestle, V., Täube, F. A., Heidenreich, S., \& Bogers, M. (2018). Establishing open innovation culture in cluster initiatives: The role of trust and information asymmetry. Technological Forecasting and Social Change.

Paglierani, P., Neokosmidis, I., Rokkas, T., Meani, C., Nasr, K. M., Moessner, K., \& Sayyad Khodashenas, P. (2020). Techno-economic analysis of 5G immersive media services in cloud-enabled small cell networks: The neutral host business model: Providing techno-economic guidelines for the successful provision of $5 \mathrm{G}$ innovative services in small cell networks. Transactions on Emerging Telecommunications Technologies, 31(2), e3746.

Saleh, S. M., Zolait, A. H., Ali, M. M., \& Wali, E. A. (2019). Investigating the Role of Information System Quality and Managerial Competency on the Organization's Performance. Paper presented at the 2019 International Conference on Innovation and Intelligence for Informatics, Computing, and Technologies (3ICT).

Shen, Q., Wang, Z., Yu, Q., Cheng, Y., Liu, Z., Zhang, T., \& Zhou, S. (2020). Removal of tetracycline from an aqueous solution using manganese dioxide modified biochar derived from Chinese herbal medicine residues. Environmental Research, 183, 109195.

Shujahat, M., Sousa, M. J., Hussain, S., Nawaz, F., Wang, M., \& Umer, M. (2019). Translating the impact of knowledge management processes into knowledge-based innovation: The neglected and mediating role of knowledge-worker productivity. Journal of Business Research, 94, 442-450.

Siuly, Li, Y., \& Wen, P. (2011). EEG signal classification based on simple random sampling technique with least square support vector machine. International journal of Biomedical Engineering and Technology, 7(4), 390-409.

Sokhanvar, S., Matthews, J., \& Yarlagadda, P. (2014). Importance of knowledge management processes in a project-based organization: A case study of research enterprise. Procedia Engineering, 97, 1825-1830.

Ul-Hameed, W., Mohammad, H., \& Shahar, H. (2018). Microfinance institute's non-financial services and women-empowerment: The role of vulnerability. Management Science Letters, 8(10), 1103-1116.

Ume, K. E., \& Ndubuaku, V. (2019). Exchange rate and foreign reserves interface: empirical evidence from Nigeria. The Economics and Finance Letters, 6(1), 1-8.

Usman, M., \& Siddiqui, D. (2019). The effect of oil price on stock market returns with moderating effect of foreign direct investment \& foreign portfolio investment: Evidence from pakistan stock market. Asian Journal of Economic Modelling, 7(2), 45-61.

Wang, H., \& Lei, J. (2020). Empirical research on the relationship between social responsibility and enterprise performance of new energy automobile enterprises in china. International Journal of Applied Economics, Finance and Accounting, 7(1), 10-23.

Williams, F., Awoyemi, A., Parakoyi, D., Jolayemi, E., \& Akande, T. (2019). Availability and Utilization of Drug Information Center, Drugs and Therapeutic Committee and Standard Treatment Guidelines in the management of HIV/AIDS patients at Public Hospitals in a North-Central State, Nigeria. Nigerian Journal of Pharmaceutical Research, 15(1), 27-34.

Woon, C. K., Singh, J. S. K., \& Singh, J. S. K. (2019). Intention to use e-recruitment system: Empirical evidence 
from jobseekers in the advertising industry in malaysia. International Journal of Business, Economics and Management, 6(2), 76-86.

Yamada, K., Itoh, M., Fujimura, Y., Kimura, M., Murata, K., Nakashima, N., . . Sueoka, E. (2019). The utilization and challenges of Japan's MID-NET® medical information database network in postmarketing drug safety assessments: A summary of pilot pharmacoepidemiological studies. Pharmacoepidemiology and drug safety, 28(5), 601-608.

Yousuf, M., Ahmed, R., Akther, N., \& Sumon, S. M. (2019). Estimating the services sector impact on economic growth of bangladesh: An econometric investigation. Asian Journal of Economic Modelling, 7(2), 62-72.

Zafarullah, M. (2018). VAT and accounting Issues and solutions in UAE. International Journal of Social and Administrative Sciences, 3(1), 35-41.

Zizakov, M., Vulanovic, S., Delic, M., Vrhovac, V., \& Vasic, S. (2019). Contribution to the Development of an Instrument for Exploring Combined Impact of Quality Management and Knowledge Management on Innovation Performances. Paper presented at the International Joint conference on Industrial Engineering and Operations Management.

\section{Copyrights}

Copyright for this article is retained by the author(s), with first publication rights granted to the journal.

This is an open-access article distributed under the terms and conditions of the Creative Commons Attribution license (http://creativecommons.org/licenses/by/4.0/). 